\title{
A comparative study of a silver stain and monoclonal antibody reactions on Alzheimer's neurofibrillary tangles
}

\author{
A A P CONNOLLY,* B A ANDERTON, $†$ M M ESIRI* \\ From the Department of Neuropathology, Radcliffe Infirmary, Oxford* and Department of Immunology, \\ St George's Hospital Medical School, London, † UK
}

SUMMARY Serial sections of brains of eight cases with Alzheimer's disease were stained by methods utilising silver and three different monoclonal antibodies. The numbers of Alzheimer's neurofibrillary tangles (NFT) were counted in the silver stained sections and compared with the numbers detected by three monoclonal anti-NF antibodies: RT97, BF10 and 8D8. The monoclonal antibody (Mab) BF10 demonstrated NFTs more clearly than Mab 8D8, but neither detected as many tangles as the silver staining method. Mab RT97 reacted well with NFTs in freshly processed specimens but not following prolonged fixation.

Some of the most widely-used techniques for the demonstration of Alzheimer's neurofibrillary tangles (NFTs) are those utilising silver impregnation because of their consistent results. ${ }^{1-10}$ Recently the possibility of using monoclonal antibodies which react with paired helical filaments or neurofilament epitopes in NFTs has been realised. ${ }^{61-14}$ It was hoped that such reactions would simplify the identification of NFTs because of their specificity. Furthermore such stains could be used both on fresh and preserved specimens. However, direct comparisons of silver and monoclonal antibody staining have rarely been performed. ${ }^{11}$ The aim of this study was to compare the use of three such monoclonal antibodies for the identification of NFTs in sections of recently fixed brains and those preserved in formalin for several years with a reliable and convenient silver method of staining.

\section{Materials and methods}

Eight cases of Alzheimer's disease with progressive dementia over several years, and with typical neuropathological

Address for reprint requests: A A P Connolly, Department of Neuropathology, Radcliffe Infirmary, Oxford, UK.

Received 8 October 1986 and in revised form 10 December 1986. Accepted 16 December 1986 findings, were selected (table 1). Brain tissues had been fixed in formalin for approximately 4 weeks before being sliced and for between 4 weeks and 10 years before being embedded in paraffin, and sections cut and stained. Eight serial $6 \mu$ sections were obtained of the hippocampus and cerebral cortex (association cortex of frontal or temporal lobe). The first and eighth sections were stained with the Cross modification of the Palmgen silver stain. ${ }^{3}$ The second/third, fourth/fifth, and sixth/seventh were stained with the monoclonal antibodies RT97, BF10 and 8D8 respectively. These antibodies were produced as previously described using as immunogen either Triton X-100-insoluble rat brain protein (RT97), Triton X-100-insoluble human brainstem (8D8), or a crude soluble protein fraction (1h at $150,000 \mathrm{~g}$ supernatant) from two pooled hippocampi (BF10). ${ }^{11}$ Previously BF10 had been shown to react predominantly with $155,000 \mathrm{MW}$ bovine neurofilament protein and the corresponding polypeptide in human brain. RT97 and 8D8 have been found to bind most strongly to the $210,000 \mathrm{MW}$ bovine neurofilament protein and equivalent human polypeptide. ${ }^{1112}$ All three monoclonal antibodies have been shown previously to react with Alzheimer's NFTs as well as with normal neurofilaments. ${ }^{11} 12$

Identical areas measuring $3 \mathrm{~mm}^{2}$ for counting were identified using the silver stained specimens. Under 230 times magnification using a Leitz Micropromar projector, which projected the field of view on to a screen, the number of NFTs in three fields on each section were counted. The fields were selected for having distinguishing vascular landmarks that enabled the same region to be identified in adjacent sections. Counts of NFTs detected by Mab BF10, 8D8 
Table 1 Number of NFTs in three areas of each section

\begin{tabular}{|c|c|c|c|c|c|c|c|c|c|c|c|c|c|c|c|c|c|c|}
\hline \multirow{3}{*}{$\begin{array}{l}\text { Case No } \\
\text { Age/sex } \\
\text { Time in } \\
\text { formalin }\end{array}$} & $I N$ & $I N$ & $I N$ & $I N$ & $2 N$ & $2 H$ & $3 N$ & $3 N$ & $4 N$ & $4 H$ & $5 N$ & $5 H$ & $6 N$ & $6 H$ & $7 N$ & $7 H$ & $8 N$ & $8 H_{\bar{O}}$ \\
\hline & \multicolumn{4}{|c|}{$73 / F$} & \multicolumn{2}{|c|}{$86 / F$} & \multicolumn{2}{|c|}{$76 / F$} & \multicolumn{2}{|c|}{$86 / F$} & \multicolumn{2}{|c|}{$88 / M$} & \multicolumn{2}{|c|}{$95 / M$} & \multicolumn{2}{|c|}{$85 / F$} & \multirow{2}{*}{\multicolumn{2}{|c|}{$\begin{array}{l}64 / F \\
10 y r\end{array}$}} \\
\hline & $3 m$ & nths & & & $7 m$ & & $2 y$ & & $2 \cdot 5$ & & $5 y$ & & $5 \cdot 5$ & & 9.5 & & & \\
\hline RT97 & $\begin{array}{l}22 \\
30 \\
17 \\
23\end{array}$ & $\begin{array}{l}6 \\
3 \\
4 \\
4\end{array}$ & $\begin{array}{l}35 \\
22 \\
25 \\
27\end{array}$ & $\begin{array}{l}1 \\
5 \\
0 \\
2\end{array}$ & $\begin{array}{l}37 \\
40 \\
21 \\
33\end{array}$ & $\begin{array}{l}4 \\
4 \\
3 \\
4\end{array}$ & $\begin{array}{l}12 \\
12 \\
15 \\
13\end{array}$ & $\begin{array}{l}6 \\
3 \\
5 \\
5\end{array}$ & $\begin{array}{l}1 \\
1 \\
1 \\
1\end{array}$ & $\begin{array}{l}- \\
-\end{array}$ & $\begin{array}{l}1 \\
1 \\
1 \\
1\end{array}$ & $\begin{array}{l}1 \\
1 \\
1 \\
1\end{array}$ & $\begin{array}{l}1 \\
1 \\
1 \\
1\end{array}$ & $\begin{array}{l}1 \\
1 \\
1 \\
1\end{array}$ & $\begin{array}{l}1 \\
1 \\
1 \\
1\end{array}$ & $\begin{array}{l}1 \\
1 \\
1 \\
1\end{array}$ & $\begin{array}{l}57 \\
63 \\
49 \\
56\end{array}$ & 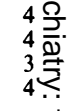 \\
\hline Silver & $\begin{array}{l}29 \\
35 \\
13 \\
26\end{array}$ & $\begin{array}{r}10 \\
2 \\
1 \\
4\end{array}$ & $\begin{array}{l}62 \\
48 \\
45 \\
48\end{array}$ & $\begin{array}{r}18 \\
12 \\
9 \\
13\end{array}$ & $\begin{array}{l}41 \\
39 \\
38 \\
39\end{array}$ & $\begin{array}{r}7 \\
15 \\
27 \\
16\end{array}$ & $\begin{array}{r}19 \\
6 \\
13 \\
13\end{array}$ & $\begin{array}{l}22 \\
11 \\
14 \\
16\end{array}$ & $\begin{array}{r}2 \\
13 \\
14 \\
8\end{array}$ & $\begin{array}{l}36 \\
15 \\
22 \\
24\end{array}$ & $\begin{array}{l}43 \\
44 \\
50 \\
46\end{array}$ & $\begin{array}{l}16 \\
25 \\
13 \\
18\end{array}$ & $\begin{array}{r}25 \\
29 \\
7 \\
20\end{array}$ & $\begin{array}{l}11 \\
10 \\
15 \\
12\end{array}$ & $\begin{array}{l}45 \\
40 \\
55 \\
47\end{array}$ & $\begin{array}{l}74 \\
42 \\
31 \\
49\end{array}$ & $\begin{array}{l}19 \\
28 \\
26 \\
24\end{array}$ & $\begin{array}{l}7 \text { ज } \\
15 \stackrel{+}{0} \\
27 \text { 음 }\end{array}$ \\
\hline BF 10 & $\begin{array}{l}12 \\
28 \\
20 \\
20\end{array}$ & $\begin{array}{l}5 \\
2 \\
3 \\
3\end{array}$ & $\begin{array}{l}20 \\
28 \\
34 \\
27\end{array}$ & $\begin{array}{l}7 \\
2 \\
3 \\
4\end{array}$ & $\begin{array}{l}15 \\
13 \\
16 \\
15\end{array}$ & $\begin{array}{l}10 \\
19 \\
20 \\
16\end{array}$ & $\begin{array}{r}6 \\
7 \\
16 \\
10\end{array}$ & $\begin{array}{r}4 \\
10 \\
8 \\
7\end{array}$ & $\begin{array}{l}2 \\
8 \\
5 \\
5\end{array}$ & $\begin{array}{l}28 \\
54 \\
58 \\
47\end{array}$ & $\begin{array}{l}69 \\
64 \\
58 \\
64\end{array}$ & $\begin{array}{l}4 \\
3 \\
2 \\
3\end{array}$ & $\begin{array}{l}44 \\
34 \\
24 \\
35\end{array}$ & $\begin{array}{l}5 \\
5 \\
4 \\
5\end{array}$ & $\begin{array}{r}13 \\
4 \\
6 \\
8\end{array}$ & $\begin{array}{r}14 \\
7 \\
10 \\
10\end{array}$ & $\begin{array}{l}- \\
-\end{array}$ & $\begin{array}{l}10 \frac{\text { จ }}{19} \\
20 \text { อ } \\
16 \text { ฝ }\end{array}$ \\
\hline 8D8 & $\begin{array}{l}19 \\
20 \\
20 \\
20\end{array}$ & $\begin{array}{l}2 \\
3 \\
3 \\
3\end{array}$ & $\begin{array}{l}32 \\
29 \\
19 \\
27\end{array}$ & $\begin{array}{l}3 \\
2 \\
1 \\
2\end{array}$ & $\begin{array}{l}42 \\
39 \\
41 \\
41\end{array}$ & $\begin{array}{l}6 \\
7 \\
6 \\
6\end{array}$ & $\begin{array}{r}4 \\
3 \\
14 \\
7\end{array}$ & $\begin{array}{l}3 \\
5 \\
4 \\
4\end{array}$ & $\begin{array}{l}4 \\
3 \\
1 \\
3\end{array}$ & $\begin{array}{l}3 \\
4 \\
3 \\
3\end{array}$ & $\begin{array}{l}30 \\
32 \\
26 \\
29\end{array}$ & $\begin{array}{l}8 \\
9 \\
3 \\
7\end{array}$ & $\begin{array}{l}17 \\
29 \\
17 \\
21\end{array}$ & $\begin{array}{l}1 \\
3 \\
1 \\
2\end{array}$ & $\begin{array}{l}17 \\
21 \\
10 \\
16\end{array}$ & $\begin{array}{l}30 \\
28 \\
21 \\
26\end{array}$ & $\begin{array}{l}- \\
-\end{array}$ & 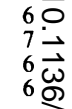 \\
\hline
\end{tabular}

Index: - , no slide; /, poor stain; $\mathrm{H}$, hippocampus; $\mathrm{N}$, neocortex.

and silver were compared using a non parametric Wilcoxon test.

\section{Results}

The most statisfactory staining with silver and the Mabs was obtained in the sections prepared from brains that had been stored in formalin for 7 months or less. In these brains most NFTs shown with silver were readily visible with all the Mabs (fig). However, NFTs were most easily seen in the silver stained sections in which there was a sharp contrast between the densely stained NFTs and the unstained background. The Mabs gave a reaction in some neurons without well defined NFTs and reacted with some elements in the rest of the neural tissue thus making interpretation more difficult. In the sections from brains immersed in formalin for 2-10 years the staining with silver progressively deteriorated. When compared with the staining obtained by the same technique in sections prepared from blocks embedded in paraffin immediately after the brains were sliced, reactions with the Mabs after prolonged formalin fixation were even more capricious. Most of these cases showed fewer NFTs with Mabs than with silver, and of the Mabs, RT97 was the least statisfactory and BF10 gave the most reliable reactios (table 1). Taking the results of counting NFTs overall, the median number counted were 18,10 and 8 per field for the silver stain and Mabs BF10 and 8D8 respectively. The difference in counts between silver and each of the Mabs was significant $(\mathrm{p}<0.002)$ but that between the two Mabs was not significant (table 2). RT97 had to be excluded
Table 2 Results of non-parametric Wilcoxon test

\begin{tabular}{lrrrr}
\hline Comparison & $N$ & Statistic & $p$ value & Median \\
\hline (Silver-BF10) & 51 & $915 \cdot 0$ & $0 \cdot 003$ & $7 \cdot 5$ \\
(Silver-8D8) & 51 & $1152 \cdot 0$ & $0 \cdot 000$ & $10 \cdot 5$ \\
(BF10-8D8) & 51 & $715 \cdot 0$ & $0 \cdot 111$ & $2 \cdot 0$ \\
\hline
\end{tabular}

from the Wilcoxon test owing to lack of satisfactory staining in the majority of cases.

\section{Discussion}

The present study demonstrated that the use of a silver stain revealed NFTs more clearly and in greater quantity than the three monoclonal antibody stains. ${ }^{10}$ Besides reacting with fewer tangles than silver, the monoclonal antibodies reacted with some neuronal perikarya lacking well defined NFTs and this made the distinction of cells with NFTs more difficult than with silver stains. ${ }^{13}$ Problems were experienced more when using the antibodies on brains that had undergone prolonged storage for several years in formalin. Thus, in our opinion a silver stain remains the method of choice for the routine demonstration of NFTs.

A common characteristic of all the staining techniques was that they all stained the NFTs with a greater degree of intensity in the freshly processed brains which had not been stored for long. For example Mab RT97 only reacted well with NFTs in the two freshly processed samples. 


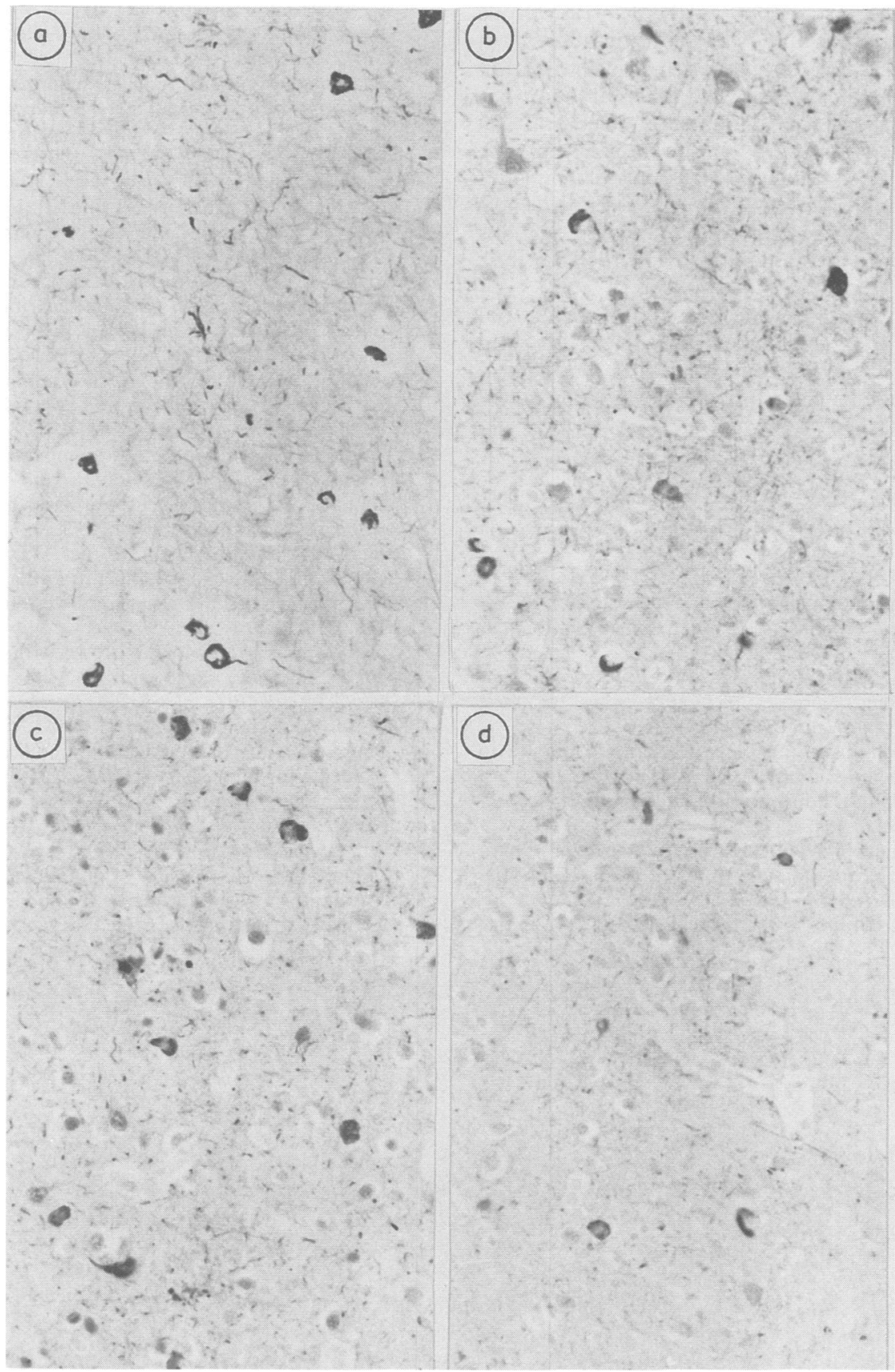

Fig In these sections the more darkly stained regions represent NFTs which have been localised by the use of silver (a) or one of the monoclonal antibodies: (b) RT97,

(c) BF10 and (d) $8 D 8 .(\times 130)$ 
The difference in stainability of NFTs with various techniques is also an important consideration. It is not only necessary for morphometric evaluation where different stains would yield different data, ${ }^{2}$ but also for analysis of the fundamental structural elements composing NFTs. ${ }^{11}{ }^{12}$ In the latter case the use of monoclonal antibodies to define neurofilament and other epitopes is essential. Mab reactions also have the advantage of working well on frozen sections which are difficult to stain with silver satisfactorily.

We thank Rowland Cross, Margaret Reading and Jacob Kahn for their technical help in carrying out this project and the Wellcome Trust and the Medical Research Council which funded the making of the antibodies.

\section{References}

1 Carson F. Nerve tissue. In: Sheehan D, Hrapchak B, eds. Theory and Practice of Histotechnology, 2nd ed. St Louis: Mosby, 1980.

2 Casanova M, Struble R, Cork L, Price D. Senile plaques in Alzheimer's disease: new approaches for their detection. Ann Neurol 1984;16:199.

3 Cross $R$. Demonstration of neurofibrillary tangles in paraffin sections: a quick and simple method using a modification of Palmgren's method. Medical Laboratory Sciences 1982;39:67-9.

4 Kurucz J, Charbonneau R, Kurucz A, Ramsey P. Quantitative clinicopathologic study of senile dementia. J Am Geriatrics Soc 1981;29:158-63.

5 Okamoto K, Hirano A, Yamaguchi H, Hirai S. The fine structure of eosinophilic stages of Alzheimer's neurofibrillary tangles. Clin Neurol 1982;22:840-6.

6 Probst A, Ulrich J, Heitz U. Senile dementia of Alzheimer's type: astroglial reaction to extracellular neurofibrillary tangles in the hippocampus: an immuno-cytochemical and electron-microscopic study. Acta Neuropathol (Berl) 1982;57:75-9.

7 Rudelli R, Ambler M, Wisniewsky H. Morphology and distribution of Alzheimer neuritic (senile) and amyloid plaques in striatum and diencephalon. Acta Neuropathol (Berl) 1984;64:273-81.

8 Pearson R, Esiri MM, Hiorns R, Wilcock G, Powell T. Anatomical correlates of the distribution of the pathological changes in the neocortex in Alzheimer's disease. Proc Natl Acad Sci 1985;82:4531-4.

9 Yamamoto T, Hirano A. Nucleus raphe dorsalis in Alzheimer's disease: neurofibrillary tangles and loss of large neurones. Ann Neurol 1985;17:573-7.

10 Yamamoto T, Hirano A. A comparative study of modified Bielschowsky, Bodian and Thioflavin $S$ stains on Alzheimer's neurofibrillary tangles. Neuropathol Appl Neurobiol 1986;12:3-9.

11 Anderton B, Breinburg D, Downes MJ, et al. Monoclonal antibodies show that neurofibrillary tangles and neurofilaments share antigenic determinants. Nature 1982;298:84-6.

12 Miller CC, Brion J, Calvert R, et al. Alzheimer's paired helical filaments share epitopes with neurofilament side arms. EMBOJ 1986;5:269-76.

13 Kahn J, Anderton B, Miller C, Wood J, Esiri MM. Staining with monoclonal antibodies to neurofilaments distinguishes between subpopulations of neurofibrillary tangles, between groups of axons and between groups of dentrites. $\boldsymbol{J}$ Neurol (in press).

14 Kahn J, Anderton B, Probst A, Ulrich J, Esiri MM Immunohistological study of granulovacuolar degeneration using monoclonal antibodies to neurofilaments. J Neurol Neurosurg Psychiatry (in press). 